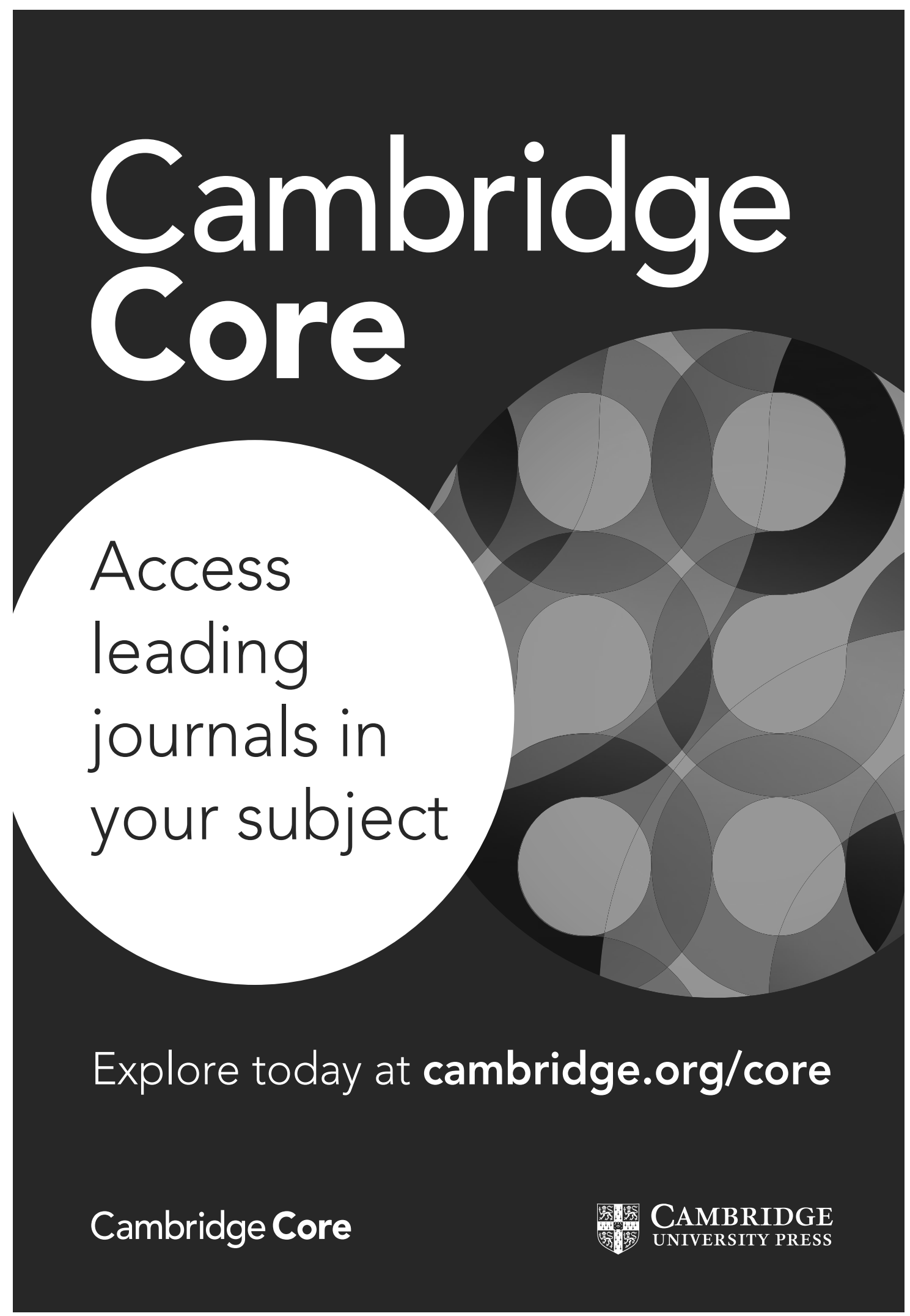




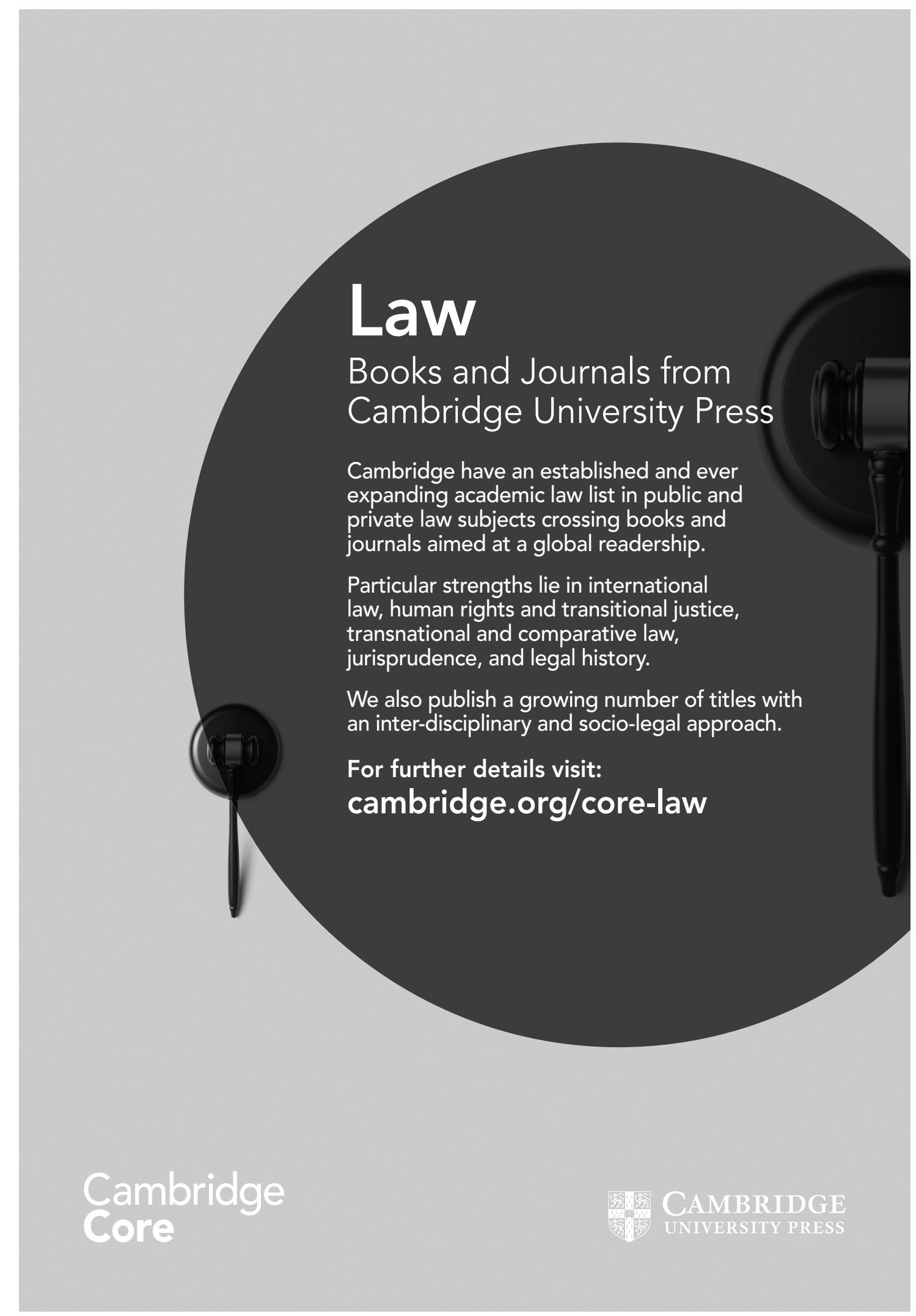




\section{INFORMATION FOR AUTHORS AND READERS}

Manuscript submission: All articles should be submitted through ScholarOne Manuscripts at http:// mc.manuscriptcentral.com/asianjls. For more information and style instructions see http://journals. cambridge.org/asianjls/IFC. For questions please contact the Managing Editor: editors@asianjls.org.

Subscriptions: The Asian Journal of Law and Society is published in May and November. The 2017 price for an online and print subscription is \$349.00 in the USA, Canada, and Mexico; UK £219.00 + VAT elsewhere. The 2018 price for an online-only subscription is $\$ 311.00$ in the USA, Canada, and Mexico; UK $£ 195.00+$ VAT elsewhere. Subscription correspondence and address changes should be sent to: Cambridge University Press, 1 Liberty Plaza, Floor 20. New York NY 10006. USA. Telephone. +1 212337 5000. email. newyork@ cambridge.org, for customers in the USA, Canada, or Mexico. Customers elsewhere should contact: Cambridge University Press, email journals@ cambridge.org. A heavily discounted personal subscription for members of the new Asian Law and Society Association can be obtained by contacting Cambridge University Press

Permissions information: All rights reserved. No part of this publication may be reproduced, in any form or by any means, electronic, photocopying, or otherwise, without permission in writing from Cambridge University Press. Policies, request forms and contacts are available at: http://journals.cambridge.org/action/ rightsAndPermissions. Permission to copy (for users in the USA) is available from Copyright Clearance Center http://www.copyright.com, email info@copyright.com.

Advertising: To advertise in the journal email USAdSales@ cambridge.org or telephone +1 (212) 3375053 in the USA, Canada or Mexico; email ad_sales@ cambridge.org or telephone +44 (1223) 325083 in the rest of the world.

Asian Journal of Law and Society is published by Cambridge Journals and the KoGuan Law School, Shanghai Jiao Tong University and is included in the Cambridge Journals Online service which can be found at http://journals.cambridge.org/asianjls

ISSN: 2052-9015

E-ISSN: 2052-9023

(C) Cambridge University Press and KoGuan Law School, Shanghai Jiao Tong University 


\section{CONTENTS}

\section{LEGAL CONSCIOUSNESS IN ASIA}

Legal Consciousness in Asia-Editors' Note to Special Issue

Lynette J. CHUA and David M. ENGEL

Foreword

Yoshitaka WADA

Legal Consciousness of the Leftover Woman: Law and Qing in Chinese Family Relations

Qian LIU

Labour Law and (In)justice in Workers' Letters in Vietnam

Tu Phuong NGUYEN

Practising on the Moon: Globalization and Legal Consciousness of Foreign Corporate Lawyers in Myanmar

Arm TUNGNIRUN

Resistance, Evasion, and Inequality: Legal Consciousness of Intellectual Property Laws in Two Chinese Markets

Lillian Hsiao-Ling SU

Constructing the Identity of the Thai Judge: Virtue, Status, and Power

Kitpatchara SOMANAWAT

Legal Consciousness as Viewed through the Judicial Iconography of the Madras High Court

Rahela KHORAKIWALA

\section{RESEARCH ARTICLES}

The Advent of Lawyers in Japanese Government

Daniel H. FOOTE

Human Rights Diffusion in North Korea: The Impact of Transnational Legal Mobilization

Patricia GOEDDE

\section{BOOK REVIEWS}

\section{ANNUAL CONFERENCE OF THE ASIAN LAW AND SOCIETY ASSOCIATION}

Presidential Address at 2017 Annual Conference of the Asian Law and Society Association (ALSA)

Hiroshi FUKURAI

Keynote Speech at 2017 Annual Conference of the Asian Law and Society Association (ALSA)

Terence C. HALLIDAY

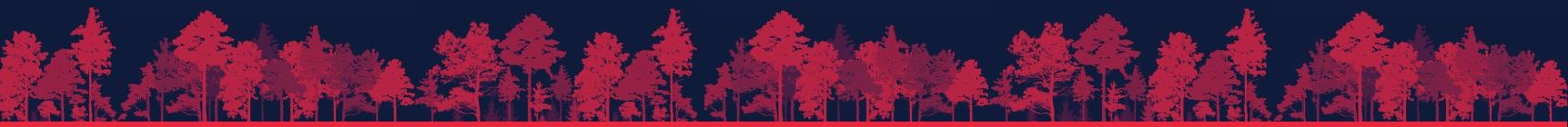

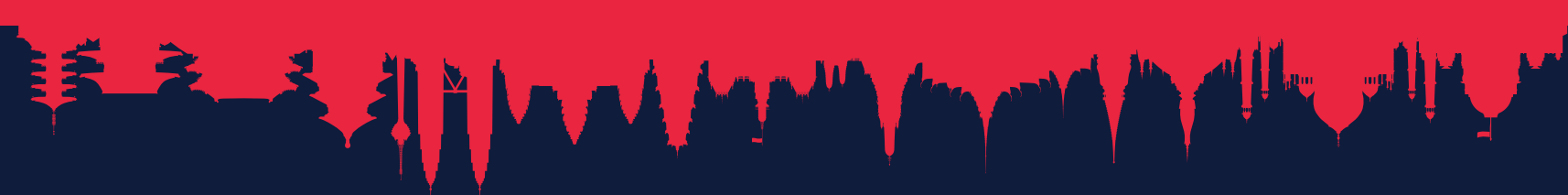

